\title{
Ecomorphological patterns in otoliths of tropical fishes: assessing trophic groups and depth strata preference by shape
}

\author{
Ivan O. Assis $(\mathbb{D} \cdot$ Victor E. L. da Silva $(1) \cdot$ Daniele \\ Souto-Vieira (D) Alfredo P. Lozano - Alejandra V. \\ Volpedo (iD) Nídia N. Fabré (iD
}

Received: 11 January 2019 / Accepted: 17 February 2020

(C) Springer Nature B.V. 2020

\begin{abstract}
The morphology and morphometry of otoliths have emerged as powerful indicators of ecological characteristics of fishes. However, shape descriptors that can accurately predict well-documented functions played by species in tropical ecosystems are either restricted to a few groups or poorly known. Therefore, we evaluated the power of two otolith shape descriptors (ecomorphological indexes and Fourier harmonics) in discriminating trophic and depth strata preference groups of tropical fish species. Differences in otolith shape of ecological groups were visualized by linear discriminant analysis (LDA), and tested by a jack-knife cross-validation method and permutational multivariate analysis of variance (PERMANOVA) for both methods. Visually and statistically, both descriptors were good predictors of trophic groups and depth preference categories (PERMANOVA, $\mathrm{p}<0.05)$. Overall jack-knifed classification success between both descriptors were very similar, with harmonics correctly classifying $90.38 \%$ of assigned trophic groups and $75.96 \%$ of given depth preference categories, against $82 \%$ and $56.25 \%$ of ecological indexes, respectively. Our results suggest that Fourier descriptors and
\end{abstract}

I. O. Assis • V. E. L. da Silva $(\bowtie) \cdot$ D. Souto-Vieira •

A. P. Lozano · N. N. Fabré

Laboratory of Ecology, Fishes and Fisheries, Institute of

Biological and Health Sciences, Federal University of Alagoas,

Maceió, Brazil

e-mail: lopesdasilvavictor@gmail.com

A. V. Volpedo

Institute of Animal Production Research, Faculty of Veterinary

Sciences, University of Buenos Aires, Buenos Aires, Argentina ecomorphological indexes of otoliths should be used as functional traits in future studies, as otolith shape provides a wider range of ecological information regarding feeding habitat, mobility, substrate association and water column use.

Keywords Ecological indicators · Feeding habit . Functional diversity $\cdot$ Sagittae $\cdot$ Surrogate

\section{Introduction}

Many dimensions of a species' niche can be assessed by the identification of relationships between morphological variation and ecological performance of organisms (Williams 1972; Winemiller 1991; Norton et al. 1995). Indeed, ecomorphological patterns found in body structures have provided numerous insights about some of the oldest issues in biology, especially in the understanding of competitive and coevolution mechanisms, and the performance capability of species (Losos 1990; Wainwright and Richard 1995; Tulli et al. 2011). In fishes, for example, the eye size and length of digestive tract have been associated to differences in foraging behavior (Watson and Balon 1984; Soares et al. 2013), the body shape has been used as a predictor of mobility in tropical species (Micheli and Halpern 2005; Passos et al. 2016; Souza et al. 2018), the relative body height is related to the fish ability to move vertically (Pouilly et al. 2003), and otolith morphology have helped to understand water-column use by species and association 
with different types of substrate (Volpedo and Echeverría 2003).

Otoliths, in particular, have been shown as good predictors of ecological characteristics of species due to their variability in shape that may result from - or be associated to - many factors (Schulz-Mirbach et al. 2006). These calcium carbonate structures are found in the inner ear of fishes, being formed and shaped throughout the life history of species by the deposition and interaction of organic matrix fibers and carbonate crystals (Morales-Nin 2000). The layer deposition process results in the formation of translucent and opaque rings as well as microscopic zones - growth increments - (Secor et al. 1992), and the overall shape of otoliths is dually regulated by genetics and the environmental history experienced by species (Lombarte and Lleonart 1993). Moreover, since otoliths are metabolically inert, elements and compounds deposited onto their growing surface produce permanent records of fishes' life cycle (Campana 1999), allowing these structures to be used as natural tags.

In Teleostei fishes, otoliths have many functions, mainly related to the sound detection (Fay and Popper 1974), notion of acceleration (Flock and Goldstein 1978) and water column positioning of the fish. The environmental sensorial perception of sagittae otoliths in non-ostariophysian fishes and its ecological implications have been vastly discussed in literature (Aguirre and Lombarte 1999; Volpedo and Echeverría 2003; Tuset et al. 2003; Volpedo et al. 2008). For SchulzMirbach et al. (2019), otolith mass and overall shape may be associated with the auditory function of fishes as the different otolith shapes may affect the endolymph flow dynamics and how the sensory epithelium functions in the semicircular canals. Therefore, if a fish has simple movements, a more spherical or ellipsoidal otolith is expected, whereas an increase in shape complexity of otoliths may be associated with higher mobility (Schellart and Popper 1992). In addition, the shape and extent of the acoustic sulcus may also play an important role in fish ecology due its close relationship with the auditory ability (Schulz-Mirbach et al. 2010; Lombarte and Tuset 2015; Tuset et al. 2016b). Lombarte and Fortuño (1992) evaluated the ratio between sulcus size (as a proxy for the macula size) and otolith size, finding correlation with the depth of the water column, whereas Aguirre and Lombarte (1999) related sulcus with the type of food and habitat used by fishes.

Although it has been discussed by many authors that otolith shape is a species-specific feature that results from the phylogenetic history of species (Wilson 1985), new studies have shown that it may also reflect patterns in the use of resources and habitats by different groups (Aguirre and Lombarte 1999; Nonogaki et al. 2007). This occurs because variability in otolith shape may result from many factors related to fish ecology, such as substrate type (Volpedo and Cirelli 2006), feeding habit (Nonogaki et al. 2007), ontogenetic shifts (Pérez and Fabré 2013) and environmental conditions - e.g. temperature and depth - (Lombarte and Lleonart 1993). Indeed, the morphology of these structures has recently been used as an indicator of roles that organisms play within ecosystems (Tuset et al. 2016a). Nevertheless, the use of otolith morphology as a functional trait - features that strongly influence organismal performance and/or individual fitness (McGill et al. 2006) - has been restricted to a few groups and species (Tuset et al. 2016a; Quinn 2018). For instance, the current knowledge on which descriptors of otolith shape can be related to well-documented functions played by fishes in tropical ecosystems is very scarce (Tuset et al. 2015).

Although there are several tools used to describe external contour and morphological patterns of otoliths - i.e. geodesic methods (Benzinou et al. 2013), wavelet functions (Sadighzadeh et al. 2014), Fourier descriptors (Tracey et al. 2006), ecomorphological indexes (Volpedo and Echeverría 2003) and geometric morphometric analysis (Ramírez-Pérez et al. 2010) -, in some cases, the biological interpretations of results may be complex because of their mathematical foundations (Stransky and MacLellan 2005). While a few advances have been achieved in the establishment of relationships between otolith shape and habitat and water column use by species (Galley et al. 2006; Jaramilo et al. 2014), the link of otolith shape to other ecological characteristics, such as feeding behavior is still poorly understood, especially for tropical fish species.

According to Gagliano and McCormick (2004), describing patterns in otoliths that reflect the feeding history of species can be a difficult task due to the intricate processes that influence otolith growth and shape. For instance, many factors that can affect feeding strategies of species - i.e. depth preference and use of substrate type - have also an impact on otoliths (Allen et al. 2006), making necessary to take a closer examination on different features of otolith morphology to identify patterns that can accurately be linked to species' feeding ecology. The identification of such patterns might be a key element in the development of new approaches for 
functional ecology (Tuset et al. 2016a), especially for species in tropical regions where studies of feeding ecology are often difficult to be carried out due to the great diversity of prey items consumed by species and high niche differentiation among and within species (Nonogaki et al. 2007; Davis et al. 2012; da Silva and Fabré 2019).

In this context, the present study aims to test whether descriptors of otolith shape can be good predictors of functions performed by fishes in tropical coastal ecosystems. The main question underlying our study is whether or not ecomorphological patterns found in otoliths can be accurately linked to ecological aspects of tropical species expressed by functional guilds. Therefore, we used discriminant and multivariate analysis to comprehend the power of different descriptors of otolith shape in identify the trophic group and depth preference of species.

\section{Materials and methods}

Sampling and otolith preparation

We sampled 208 otoliths of 33 species collected along the coast of Alagoas $\left(09^{\circ} 47^{\prime} 80.4^{\prime \prime} \mathrm{S} ; 35^{\circ} 49^{\prime} 56^{\prime \prime} \mathrm{W}\right.$ and $\left.10^{\circ} 21^{\prime} 26.8^{\prime \prime} \mathrm{S} ; 36^{\circ} 05^{\prime} 32.9^{\prime \prime} \mathrm{W}\right)$, located in the tropical south-west Atlantic ecoregion of the north-east Brazil (Fig. 1). This coastline is characterized by a narrow continental shelf $(50 \mathrm{~km})$, and it is influenced by the many reef formations, lagoons and estuarine areas found in the region (Medeiros et al. 2007). Fishes were collected by ten nylon gillnets linked by ropes in a chain arrangement in 18 sampling sites distributed along the coast (Federal Scientific Fish Sampling License $1,837,810$ ). The chain of 10 nets was $100 \mathrm{~m}$ long and $2.9 \mathrm{~m}$ high with mesh sizes that ranged from 20 to $80 \mathrm{~mm}$ randomly located along the chain. Four sampling surveys were undertaken in January, April, May and July 2013, encompassing the two well-established seasons of the study area (dry and wet seasons).

In laboratory, fishes were identified at level species using regional taxonomic keys (Figueiredo and Menezes 1978, 1980; Menezes and Figueiredo 1980, 1985), measured to the nearest $\mathrm{mm}$ (total length) and sexed. Otoliths were removed using the open-thehatch technique as described by Secor et al. (1992), cleaned from tissues with $5 \% \mathrm{NaOH}$, washed with distilled water, dried and stored in labeled vials. To avoid the effect of ontogenetic variability, only otoliths from sexually mature specimens were used in this study (Stransky and MacLellan 2005), hence, maturity stage of individuals was assigned using macroscopic gonadal examination following Vazzoler (1996). A digital picture of the left sagittae from each individual was taken using a stereoscopic binocular microscope Leica S8-APO equipped with a camera Leica EC3. Otoliths were always positioned with their respective dorsal margin to the top of the image, anterior (rostral) region to the left and sulcus-side-up.
Fig. 1 Map of study area showing sampling sites $(\bullet)$ and depth strata (grey lines) where sampling surveys were carried out

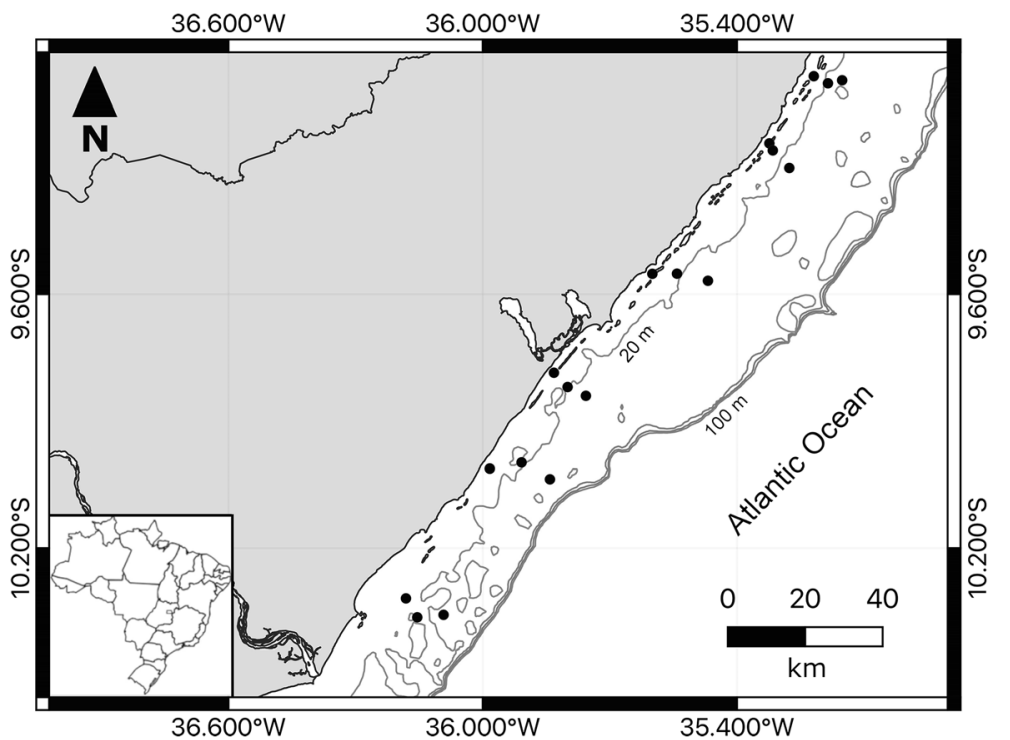


The morphology of otoliths was described by two different approaches. First, we calculated four ecomorphological indexes (see Table 1 for details) to identify patterns in otolith form: the E, R and S indexes which describe otolith shape and dimensions (Volpedo and Echeverría 2003; Volpedo et al. 2008), and an edge complexity index (EC) based on Kalff's shoreline development factor (SFD) which was used to describe irregularities on otoliths' edge (Kalff 2002). These indexes were calculated using the following morphometrical measurements, which were record in millimeters ( $\mathrm{mm}$ ) for all otoliths using the shapeR package in the R statistic software (Libungan and Pálsson 2015)- otolith length (OL), otolith width (OW), otolith area $(\mathrm{OA})$ and otolith perimeter $(\mathrm{OP})$ - and the image processing system ImageJ (Rasband 2012): rostrum length (RL) and sulcus area (SA). All measurements were size-corrected before analysis to ensure unbiased comparisons between groups (Reist 1985). Second, we retrieved the elliptic Fourier descriptors (EFD) for each otolith using the shape R package in the $\mathrm{R}$ statistics software (Kuhl and Giardina 1982; Lestrel 1997). This method is considered one of the best techniques for capturing the entire shape variation and small-scale individual differences (Campana and Casselman 1993), allowing the deconstruction of otolith shape in orthogonal series, which are called harmonics. Harmonics represent a series of sine and cosine curves that are generated by a Fourier expansion, taking the elliptic shape as reference (Younker and Ehrlich 1977; Bird et al. 1986).

Data analysis

Prior to analysis, studied species were categorized according to a trophic group and a depth strata preference category (see Table 2 for species' classification), which are two ecological features of species commonly related to functions performed by them in ecosystems. Fishes were assigned to a trophic group based on the main diet of adults according to existing published data. To promote uniformity in the trophic group classification of species, the categories used herein followed Ferreira et al. (2004): carnivorous (fishes that feed predominately on sessile invertebrates, but may also feed on other organisms, including fishes); mobile invertebrate feeders (fishes that only feed on mobile invertebrates); omnivorous (fishes that feed on a variety of food items, including planktonic, benthic and nektonic organisms) and piscivorous (fishes that feed mainly on other fish species). Depth preference was assigned using data found in online databases such as FishBase, taking in consideration three depth strata: shallow $(0-40 \mathrm{~m})$, medium (41-60 m) and deep (61-150 m).

To evaluate whether ecomorphological indexes and harmonics could be used as a tool for distinguishing trophic and depth preference groups, linear discriminant analysis (LDA) were carried in the PAST statistics software. The LDA reduces the ratio of within-class variance and maximizes the ratio of between-class variance, seeking directions on space that have maximum discriminability among given classes (Rezzi et al. 2007), making this analysis a powerful tool in the identification of groups. In addition to graphic visualization, to evaluate the effective discriminant power of both descriptors (harmonics and ecomorphological indexes), we first used a jack-knife method for the estimation of the classification error, and statistically test differences among and within groups by permutational multivariate analysis of variance PERMANOVA - (Anderson 2017).

Additionally, the mean contour of each group (trophic and depth preference) was reconstructed by the

Table 1 Ecomorphological indexes used to identify patterns in otoliths of tropical fishes collected in the south-west Atlantic

\begin{tabular}{|c|c|c|c|}
\hline Indexes & Meaning & Formula & Reference \\
\hline $\mathrm{EC}$ & Describes edge irregularities in otoliths & $E C=\frac{O P}{2^{*} \sqrt{O A^{*} \pi}}$ & Kalff (2002) \\
\hline $\mathrm{E}$ & $\begin{array}{l}\text { Expresses the tendency in the shape of the } \\
\text { sagittae (circular or elongate) }\end{array}$ & $E=\frac{O A}{O L}$ & Volpedo and Echeverría (2003) \\
\hline $\mathrm{R}$ & $\begin{array}{l}\text { Expresses how much of the otolith length } \\
\text { that corresponds to the rostrum }\end{array}$ & $R=\frac{R L}{O L}$ & Volpedo and Echeverría (2003) \\
\hline $\mathrm{S}$ & $\begin{array}{l}\text { Tendency of macula nervous to have a greater } \\
\text { surface area of information uptake to transmit } \\
\text { to the fish brain }\end{array}$ & $S=\frac{S A}{O A}$ & Gauldie (1988) \\
\hline
\end{tabular}


Table 2 Average ecomorphological indexes values for species collected in the south-west Atlantic and their respective trophic groups "TG" (Carn - carnivorous, MIF - mobile invertebrate feeders, Omn - omnivorous, Pisc - piscivorous) and depth preference categories "DP" (shallow, medium and deep)

Family / Species

$\mathrm{N}$

Ecomorphological indexes

TG

DP

Albulidae

Albula nemoptera ${ }^{1}$

Albula vulpes ${ }^{2}$

Bothidae

Bothus ocellatus ${ }^{3}$

Carangidae

Caranx crysos ${ }^{4}$

Chloroscombrus chrysurus ${ }^{5}$

Oligoplites saurus $^{6}$

Clupeidae

Opisthonema oglinum ${ }^{7}$

Cynoglossidae

Symphurus tessellatus ${ }^{8}$

Gerreidae

Diapterus rhombeus ${ }^{9}$

Eucinostomus argenteus ${ }^{9}$

Haemulidae

Conodon nobilis ${ }^{10}$

Haemulon aurolineatum ${ }^{11}$

Haemulon steindachneri ${ }^{12}$

Haemulopsis corvinaeformis ${ }^{13}$

Orthopristis ruber ${ }^{14}$

Lutjanidae

Lutjanus analis ${ }^{3}$

Lutjanus synagris ${ }^{11}$

Mullidae

Pseudupeneus maculatus $^{3}$

Paralichthyidae

Syacium $_{\text {micrurum }}{ }^{15}$

Sciaenidae

Cynoscion jamaicensis ${ }^{16}$

Larimus breviceps ${ }^{17}$

Macrodon ancylodon ${ }^{18}$

Menticirrhus americanos ${ }^{19}$

Micropogonias furnieri ${ }^{20}$

Paralonchurus brasiliensis ${ }^{21}$

Stellifer brasiliensis ${ }^{22}$

Umbrina coroides ${ }^{14}$

Scombridae

Scomberomorus brasiliensis ${ }^{23}$
Scomberomorus cavalla $^{24}$

3

16

1.19

1.18

1

1.05

1.39

1.26

18

1.23

30

1.45

2

1.02

30

1.15

1.16

1.09

7

16

1.07

2

1.07

1.08

1.09

10

1.11

1.12

11

1.18

1.08

10

1.13

1.07

1.18

1.24

1.07

1.15

1.12

1.05

3

5

3

1.21

1.35
E

0.43

0.55

0.63

0.40

0.46

0.58

0.47

1.08

0.64

0.57

0.66

0.68

0.69

0.71

0.61

0.56

0.60

0.74

0.70

0.61

0.67

0.74

0.38

0.78

0.46

0.64

0.68

0.51

0.50
R

S

Carn

Medium

0.40

Carn

Shallow

0.30

Carn

Deep

0.29

Pisc

Deep

0.22

Omn

Deep

0.31

0.33

Carn

Medium

0.36

0.37

Omn

Medium

0.15

MIF

Medium

0.24

Carn

Deep

0.24

Carn

Medium

Deep

Shallow

Medium

Medium

Deep

0.22

MIF

MIF

0.29

Carn

Medium

0.30

Carn

Medium

0.19

0.30

Carn

Deep

0.42

MIF

Deep

0.51

Carn

Deep

0.48

MIF

Medium

0.49

Carn

Medium

0.57

Carn

Medium

0.43

MIF

Medium

0.54

MIF

Medium

0.33

MIF

Medium

0.50

MIF

Shallow

0

0.32

0.33

Pisc

Medium

0.33

0.40

Pisc

Shallow 
Table 2 (continued)

\begin{tabular}{|c|c|c|c|c|c|c|c|}
\hline \multirow[t]{2}{*}{ Family / Species } & \multirow[t]{2}{*}{$\mathrm{N}$} & \multicolumn{4}{|c|}{ Ecomorphological indexes } & \multirow[t]{2}{*}{ TG } & \multirow[t]{2}{*}{ DP } \\
\hline & & EC & $\mathrm{E}$ & $\mathrm{R}$ & $\mathrm{S}$ & & \\
\hline \multicolumn{8}{|l|}{ Serranidae } \\
\hline Diplectrum formosum ${ }^{25}$ & 2 & 1.22 & 0.46 & 0.24 & 0.22 & MIF & Deep \\
\hline \multicolumn{8}{|l|}{ Sparidae } \\
\hline Calamus pennatula ${ }^{25}$ & 1 & 1.22 & 0.43 & 0.20 & 0.38 & MIF & Shallow \\
\hline \multicolumn{8}{|l|}{ Sphyraenidae } \\
\hline Sphyraena guachancho ${ }^{26}$ & 5 & 1.25 & 0.36 & 0.13 & 0.36 & Pisc & Deep \\
\hline \multicolumn{8}{|l|}{ Stromateidae } \\
\hline Peprilus paru ${ }^{19}$ & 1 & 1.11 & 0.61 & 0.21 & 0.32 & Carn & Medium \\
\hline
\end{tabular}

sum of the harmonics using the SHAPE software (Iwata and Ukai 2002) to visualize patterns in otolith shape. The Fourier harmonics were normalized in relation to the first harmonic - represented by a displacement circle with barely no information about the original shape (Kuhl and Giardina 1982; Iwata and Ukai 2002) -, and the mean contour as well as its standard deviation were formed by the outline reverse Fourier transform. All statistical analyses were performed at a significance level of $\mathrm{p}<0.05$.

\section{Results}

Among the 45 Fourier harmonics extracted to describe otolith shape, the first 12 harmonics explained more than $99.99 \%$ of variation and were thus used for the multivariate analysis. Although harmonics were able to visually discriminate both trophic and depth preference groups better than ecomorphological indexes (Figs. 2 and 3), overall jack-knifed classification success between both descriptors were very similar, with harmonics correctly classifying $90.38 \%$ of assigned trophic groups and $75.96 \%$ of given depth preference categories, against $82 \%$ and $56.25 \%$ of ecological indexes, respectively (Tables 3 and 4). In both descriptors, misclassification percentages among trophic groups were particularly high between mobile invertebrate feeders and carnivorous species, while considering depth preference categories greater similarity was found among species from medium and deep depths (Tables 3 and 4).

Statistically, both descriptors were good predictors of trophic groups and depth preference categories (PERMANOVA, Pseudo-P < 0.05), however no interactions between these two factors were found (Pseudo-P = 0.998). Differences in average shapes between trophic groups and depth preference categories could be observed by the reconstructed outlines of the mean Fourier harmonics. The main shape difference between trophic groups occurred in otolith elongation due to rostrum development and complexity, with piscivorous and omnivorous species presenting a more developed rostrum and elongated otolith with high complexity, while carnivorous and mobile invertebrate feeders individuals showed a tendency towards a rounded shape (Fig. 2). Considering the depth preference categories, otoliths of species living in deeper depths showed a rounded shape in comparison to otoliths of the ones from shallow waters (Fig. 3).

\section{Discussion}

In our study, both studied descriptors of otolith morphology were good predictors of features related to tropical species' ecology, such as trophic groups and depth strata preference. In both methods, species in the same group clustered together regardless variability in 


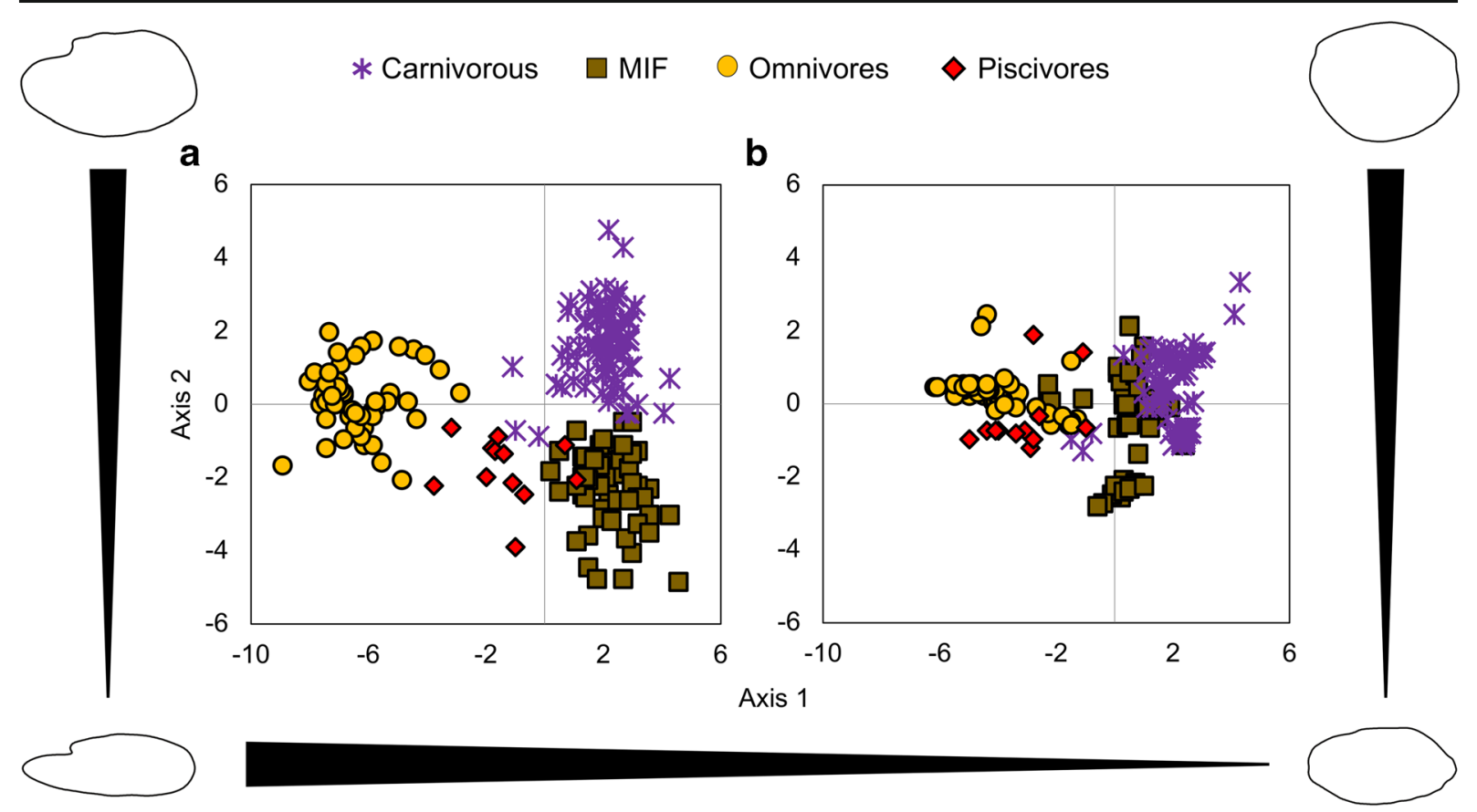

Fig. 2 Linear discriminant analysis scores for the classification of trophic guilds of studied species based on Fourier descriptors (a) and ecomorphological indexes (b)

body shape and phylogenetic relationships, indicating that otoliths can retain a wider range of ecological information in their shape, which can be retrieved from simpler analysis such the use of ecomorphological indexes, or more complex methods like the use of geomorphometric analysis.

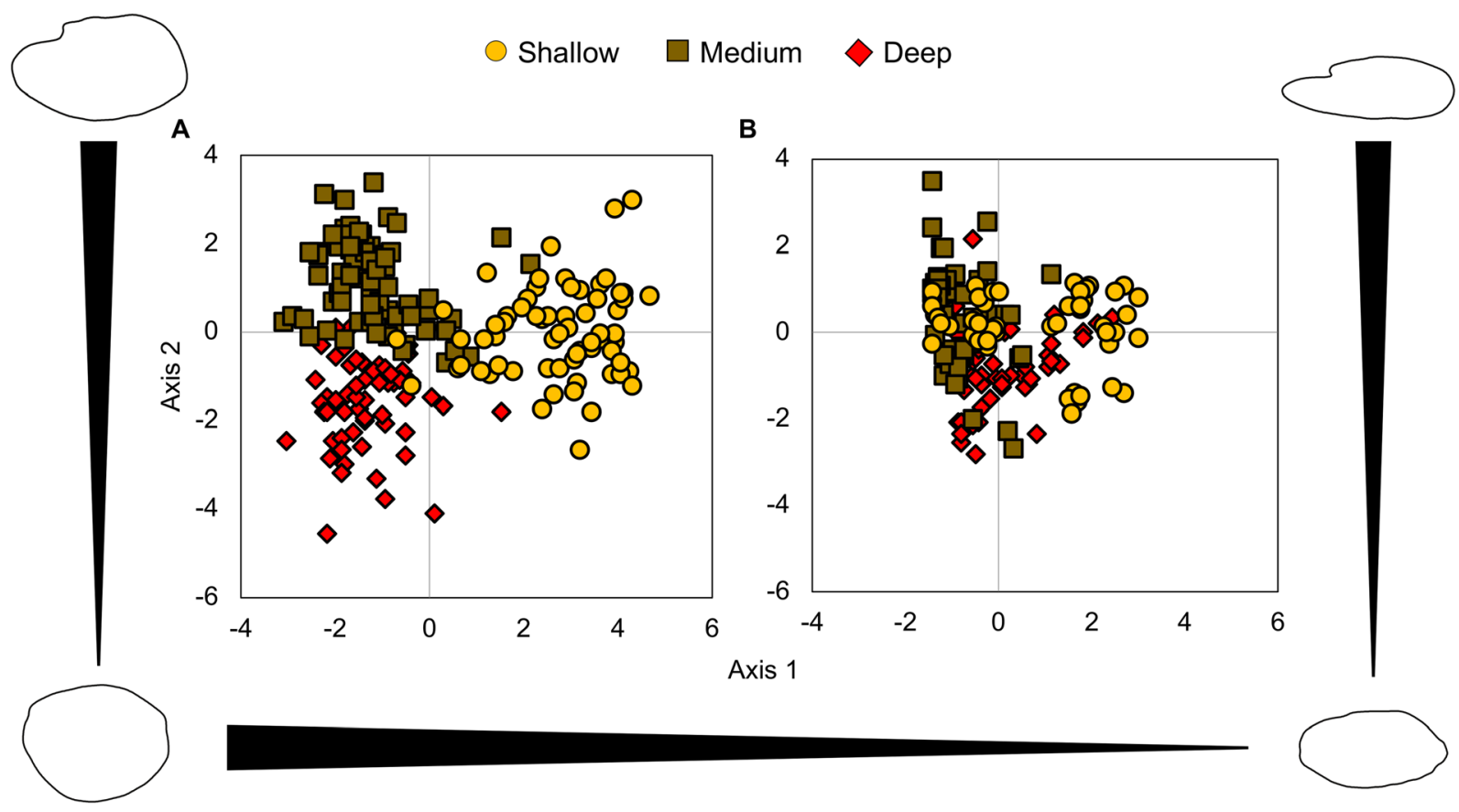

Fig. 3 Linear discriminant analysis scores for the classification of depth strata preference of studied species based on Fourier descriptors (a) and ecomorphological indexes (b) 
Table 3 Jack-knifed classification matrix - in percentage - for the LDA analysis of studied fish trophic groups with ecomorphological indexes and eliptic Fourier descriptors (Carn - carnivorous; MIF - mobile invertebrate feeders; Omn - omnivorous; Pisc - piscivorous)

\begin{tabular}{|c|c|c|c|c|c|c|c|c|}
\hline \multirow[b]{2}{*}{ Groups } & \multicolumn{4}{|c|}{ Ecomorphological indexes (\%) } & \multicolumn{4}{|c|}{ Fourier descriptors (\%) } \\
\hline & Carn & MIF & Pisc & Omn & Carn & MIF & Pisc & Omn \\
\hline Carn & 71 & 23 & 4 & 2 & 86 & 7 & 5 & 2 \\
\hline MIF & 6 & 93 & 1 & 0 & 4 & 94 & 2 & 0 \\
\hline Pisc & 0 & 0 & 67 & 33 & 33 & 0 & 67 & 0 \\
\hline Omn & 2 & 0 & 20 & 78 & 2 & 0 & 2 & 96 \\
\hline
\end{tabular}

Although ecomorphological indexes were not able to visually distinguish trophic groups or depth strata categories as Fourier harmonics did (Figs. 2 and 3), both methods can clearly indicate differences between different ecological groups as shown by PERMANOVA and jack-knifed cross-validation results. In general, harmonics have been considered a powerful method to describe otolith shapes comprehensively (Lestrel 1997), especially when it come to understand ecological features of species since this method captures the entire shape variation and small-scale individual differences (Gagliano and McCormick 2004). However, our results show that ecomorphological indexes can also be good descriptors of ecological functions, despite being simpler indicators of morphology (Mahe et al. 2016).

In previous works, ecomorphological indexes have been widely used to describe water column use and associations to different types of substrate (Volpedo and Echeverría 2003; Volpedo et al. 2008), but in the present study, their combination with Fourier harmonics allowed us to identify relationships with other aspects of species' ecology. For example, piscivorous and omnivorous species presented otoliths with a tendency towards a more elongated shape, pronounced rostrum and high complexity which enhance fishes' swimming capability and help in prey detection and capture due to specialization in acoustic communication (O'Toole et al. 2010; Ferguson et al. 2015; Schrandt et al. 2015). Moreover, as preys consumed by these groups are often found in the middle of the water column, some adaptive aspects, such as a well-developed rostrum, are required to support a high luminosity and noisy pelagic environment near the sea surface (Begg and Hopper 1997; Paxton 2000; Lombarte and Cruz 2007). This feature allow species to process information faster than sedentary species, making them quicker swimmers and enhancing its ability to capture preys (Lychakov and Redbane 1993; Popper et al. 2005). Additionally, higher edge complexity found for piscivorous and omnivorous species may be associated to greater levels of food consumption, as it has been shown by studies that otolith lobes' formation depends on the protein accretion process (Hüssy 2008).

On the other hand, carnivorous and mobile invertebrate feeders were characterized by otoliths with rounded shape, regular edges and smaller or not-developed rostrum. Fish species in these groups feed mainly on organisms associated with the substrate - e.g., crustaceous, polychaetas -, which do not require them to move up in the water column (Crabtree et al. 1998; Marques et al. 2009), neither a great swimming performance to capture their preys (Freitas et al. 2011;

Table 4 Jack-knifed classification matrix - in percentage - for the LDA analysis of depth preference strata for studied fish with ecomorphological indexes and eliptic Fourier descriptors

\begin{tabular}{|c|c|c|c|c|c|c|}
\hline \multirow[b]{2}{*}{ Groups } & \multicolumn{3}{|c|}{ Ecomorphological indexes $(\%)$} & \multicolumn{3}{|c|}{ Fourier descriptors $(\%)$} \\
\hline & Shallow & Medium & Deep & Shallow & Medium & Deep \\
\hline Shallow & 57 & 34 & 9 & 83 & 8 & 9 \\
\hline Medium & 4 & 63 & 33 & 7 & 72 & 21 \\
\hline Deep & 18 & 28 & 54 & 1 & 25 & 74 \\
\hline
\end{tabular}


Denadai et al. 2015). Our results agree with Volpedo et al. (2008) which found that not active swimmers exhibit tendency towards a rounded otolith.

In relation to patterns found in otoliths associated to depth strata preference of species, the presence of fishes with elongated otoliths in coastal and shallow areas goes against the expected. According to Lombarte and Cruz (2007), otolith size tends to increase with depth as a compensatory response to the reduction of light. However, the pattern found in our study may be explained by the narrow extension of the oceanic shelf in the studied region $(50 \mathrm{~km})$, which allows pelagic species to undertake migratory movements to coastal and estuarine areas for feeding or reproduction (Kadison et al. 2010). One reason for this investment in migratory movements may be associated to the estuarization process that occurs in the tropical region (Passos et al. 2016) which creates a highly productive zone that attracts species from deeper regions.

Furthermore, it is important to notice that otolith morphology was able to identify trophic groups despite body shape similarities and phylogenetic relationships among studies species. For example, although the three studied carangid species in our paper have a close phylogenetic relationship and resembling body structures, they were all clustered separately, being placed near to species that share similar feeding habits with them. Comparable results were found for Gagliano and McCormick (2004) that showed that otolith shape embodies a sensitive record of individual recent feeding histories independently of their size or age. Factors that allow morphological patterns in otoliths to accurately reflect ecological characteristics of species include their lack of extreme morphologies - which strongly influence ecomorphological indexes - (Tuset et al. 2016a), and the fact that otolith shape is a species-specific feature formed throughout fish life-history (Wilson 1985) which allows the retaining of information regarding habitat use, locomotion, mobility and feeding behavior (Volpedo and Echeverría 2003; Lombarte and Cruz 2007; Volpedo et al. 2008).

In summary, our results show that ecomorphological patterns and Fourier harmonics are good predictors of ecological groups of tropical fishes, providing a wider range of information regarding the feeding strategies and habitat use by species. Such information is of great importance to estimate the functional structure of assemblages and help us to understand more about the role played by species in the ecosystems (da Silva et al.
2019). Therefore, we conclude that Fourier descriptors and ecomorphological indexes that are associated to the shape, rostrum length and sulcus area of otoliths can be included in future studies as functional traits in order to obtain a more realistic picture of how functionally diversity the studied communities are. Besides that, in our work we had an approach exploring 2D data (e.g., linear measures), for the future, we intend to add $3 \mathrm{D}$ data, which may provide new insights about functional characteristics of otoliths.

Acknowledgments We would like to thank colleagues Carol Passos, Marcia Sousa, Rosa Costa and Vandick Batista for their assistance during field and laboratory work, and Richard Ladle for checking the English of the manuscript. This research was funded by the Brazilian National Council for Scientific and Technological Development - CNPq (N. Fabré, grant \#306624/2014-1) and the Coordination for the Improvement of Higher Education Personnel - CAPES. Data collection and analysis was funded by a grant from the State Funding Agency of Alagoas (FAPEAL) and the Brazilian Ministry of Fisheries and Aquaculture (MPA). The research was carried out in accordance with the principles of the Basel Declaration and following the recommendations of the Brazilian Animal Protection Law. All procedures were approved by the System of Biodiversity Authorization and Information (SISBIO committee) under the license \#13392.

\section{References}

Adams A, Guindon K, Horodysky A, MacDonald T, McBride R, Shenker J, Ward R (2012) Albula nemoptera

Aguirre H, Lombarte A (1999) Ecomorphological comparisons of sagittae in Mullus barbatus and M. surmuletus. J Fish Biol 55:105-114. https://doi.org/10.1006/jfbi.1999.0974

Akadje C, Diaby M, Le Loc'h F, Konan JK, N'Da K (2013) Diet of the barracuda Sphyraena guachancho in Côte d'Ivoire (equatorial eastern Atlantic Ocean). Cybium. 37:285-293

Allen LG, Pondella DJ, Horn MH (2006) Ecological classification. In: the ecology of marine fishes: California and adjacent waters. Univ of California press, pp 81-114

Anderson M. J (2017) Permutational multivariate analysis of variance (PERMANOVA). Wiley StatsRef Stat Ref Online 1-15. doi: https://doi.org/10.1002/9781118445112.stat07841

Begg GA, Hopper GA (1997) Feeding patterns of school mackerel (Scomberomorus queenslandicus) and spotted mackerel (S. munroi) in Queensland east-coast waters. Mar Freshw res. https://doi.org/10.1071/MF97064

Benzinou A, Carbini S, Nasreddine K et al (2013) Discriminating stocks of striped red mullet (Mullus surmuletus) in the northwest European seas using three automatic shape classification methods. Fish Res 143:153-160. https://doi.org/10.1016 /j.fishres.2013.01.015

Bessa E, Santos FB, Pombo M, Denadai M, Fonseca M, Turra A (2014) Population ecology, life history and diet of the shorthead drum Larimus breviceps in a tropical bight in 
southeastern Brazil. J Mar Biol Assoc United Kingdom 94: 615-622. https://doi.org/10.1017/S0025315413001690

Bird JL, Eppler DT, Checkley DM (1986) Comparisons of herring otoliths using fourier series shape analysis. Can J Fish Aquat Sci 43:1228-1234. https://doi.org/10.1139/f86-152

Bowman R. E, Stillwell C. E, Michaels W. L, Grosslein M. D (2000) Food of Northwest Atlantic fishes and two common species of squid. NOAA technical memorandum NMFS-NE155. https://www.nefsc.noaa.gov/publications/tm/tm155/. Accessed 18 November 2018

Campana S (1999) Chemistry and composition of fish otoliths: pathways, mechanisms and applications. Mar Ecol Prog Ser 188:263-297. https://doi.org/10.3354/meps 188263

Campana SE, Casselman JM (1993) Stock discrimination using otolith shape analysis. Can J Fish Aquat Sci 50:1062-1083. https://doi.org/10.1139/f93-123

Castro D. N, de Lima W. M. G, Mendes N. C. B, do Nascimento M. S, de Freitas Lutz Í. A, Cardoso C. D. N. A, da Silva B. B (2015) Dieta natural de Macrodon ancylodon (Bloch\& Schneider, 1801) capturada por embarcações pesqueiras industriais sediadas no Estado do Pará. Biota Amaz 5:5054. doi: https://doi.org/10.18561/2179-5746/biotaamazonia. v5n3p50-54

Chaves PDTDC, Umbria SC (2003) Changes in the diet composition of transitory fishes in costal systems, estuary and continental shelf. Brazilian Arch Biol Technol 46:41-46. https://doi.org/10.1590/S1516-89132003000100007

Crabtree RE, Stevens C, Snodgrass D, Stengard FJ (1998) Feeding habits of bonefish, Albula vulpes, from the waters of the Florida keys. Fish Bull 96:754-766

da Silva VEL, Fabré NN (2019) Rare species enhance niche differentiation among tropical estuarine fish species. Estuar Coasts 42:890-899. https://doi.org/10.1007/s12237-01900524-2

da Silva VEL, Silva-Firmiano LPS, Teresa FB et al (2019) Functional traits of fish species: adjusting resolution to accurately express resource partitioning. Front Mar Sci 6:1-11. https://doi.org/10.3389/fmars.2019.00303

Davis B, Johnston R, Baker R, Sheaves M (2012) Fish utilisation of wetland nurseries with complex hydrological connectivity. PLoS One 7. https://doi.org/10.1371/journal.pone.0049107

Denadai MR, Santos FB, Bessa E, Fernandez WS, Lorca L, Turra A (2013) Population biology and diet of Pomadasys corvinaeformis (Perciformes: Pomadasyidae) in Caraguatatuba Bay, southeastern Brazil. Rev Biol Trop 61: 1947-1954

Denadai MR, Santos FB, Bessa E, Fernandez WS, Paschoal CC, Turra A (2012) Diets of Eucinostomus argenteus (Baird \& Girard, 1855) and Diapterus rhombeus (Cuvier, 1829) (Perciformes: Gerreidae) in Caraguatatuba Bay, southeastern Brazil. Panam J Aquat Sci 7:143-155

Denadai MR, Santos FB, Bessa E et al (2015) Feeding habits of whitemouth croaker Micropogonias furnieri (Perciformes: Sciaenidae) in Caraguatatuba Bay, southeastern Brazil. Brazilian J Oceanogr 63:125-134. https://doi.org/10.1590 /S1679-87592015084706302

DeVane JC (1978) Food of king mackerel, Scomberoomorus cavalla, in Onslow Bay, North Carolina. Trans Am Fish Soc 107:583-586. https://doi.org/10.1577/1548-8659(1978 )107<583:FOKMSC >2.0.CO;2
Duque-Nivia G, Acero PA, Santos-Martinez A, Rubio ER (1996) Food habits of the species of the genus Oligoplites (Carangidae) from the Cienaga Grande de Santa MartaColombian Caribbean. Cybium 20:251-260

Estrada M (1986) Habitos alimentarios de los peces del genero Haemulon (Pisces: Haemulidae) de los arrecifes de la region de Santa Marta, Colombia. An Inst Investig Mar 15(16):4966. https://doi.org/10.25268/bimc.invemar.1986.15.0.464

Fay BYRR, Popper AN (1974) Acoustic stimulation of the ear of the goldfish (Carassius auratus). J Exp Biol:243-260

Ferguson AR, Huber DR, Lajeunesse MJ, Motta PJ (2015) Feeding performance of king mackerel, Scomberomorus Cavalla. J Exp Zool Part A Ecol Genet Physiol 323:399413. https://doi.org/10.1002/jez.1933

Ferreira CEL, Floeter SR, Gasparini JL et al (2004) Trophic structure patterns of Brazilian reef fishes: a latitudinal comparison. J Biogeogr 31:1093-1106. https://doi.org/10.1111 j.1365-2699.2004.01044.x

Figueiredo JL, Menezes NA (1980) Manual de Peixes Marinhos do Sudeste do Brasil. III. Teleostei (2). Museu de Zoologia. Universidade de São Paulo, São Paulo

Figueiredo JL, Menezes NA (1978) Manual de Peixes Marinhos do Sudeste do Brasil. II. Teleostei (1). Museu de Zoologia. Universidade de São Paulo, São Paulo

Flock A, Goldstein MH (1978) Cupular movement and nerve impulse response in the isolated semicircular canal. Brain Res 157:11-19. https://doi.org/10.1016/0006-8993(78 90992-7

Freitas MO, Abilhoa V, da Costa Silva GH (2011) Feeding ecology of Lutjanus analis (Teleostei: Lutjanidae) from Abrolhos Bank, eastern Brazil. Neotrop Ichthyol 9:411-418. https://doi.org/10.1590/S1679-62252011005000022

Gagliano M, McCormick MI (2004) Feeding history influences otolith shape in tropical fish. Mar Ecol Prog Ser 278:291296. https://doi.org/10.3354/meps278291

Galley EA, Wright PJ, Gibb FM (2006) Combined methods of otolith shape analysis improve identification of spawning areas of Atlantic cod. ICES J Mar Sci. https://doi. org/10.1016/j.icesjms.2006.06.014

Gómez-Canchong P, Manjarrés LM, Duarte LO, Altamar J (2004) Atlas pesquero del area norte del Mar Caribe de Colombia. Universidad del Magadalena, Santa Marta

Guedes AP, Araújo FG, de Azevedo MCC (2004) Estratégia trófica dos linguados Citharichthys spilopterus Günther e Symphurus tessellatus (Quoy \& Gaimard) (Actinopterygii, Pleuronectiformes) na Baía de Sepetiba, Rio de Janeiro, Brasil. Rev Bras Zool 21:857-864

Hüssy K (2008) Otolith shape in juvenile cod (Gadus morhua): ontogenetic and environmental effects. J Exp Mar Bio Ecol 364:35-41. https://doi.org/10.1016/j.jembe.2008.06.026

Iwata H, Ukai Y (2002) SHAPE: a computer program package for quantitative evaluation of biological shapes based on elliptic Fourier descriptors. J Hered. https://doi.org/10.1093 /jhered/93.5.384

Jaramilo AM, Tombari AD, Benedito Dura V et al (2014) Otolith eco-morphological patterns of benthic fishes from the coast of Valencia (Spain). Thalassas 30:57-66

Kadison E, D'Alessandro EK, Davis GO, Hood PB (2010) Age, growth, and reproductive patterns of the great barracuda, Sphyraena Barracuda, from the Florida keys. Bull Mar Sci 86:773-784. https://doi.org/10.5343/bms.2009.1070 
Kalff J (2002) Limnology: inland water ecosystems. Prentice Hall, New Jersey

Kehrig HA, Seixas TG, Di Beneditto APM, Malm O (2013) Selenium and mercury in widely consumed seafood from South Atlantic Ocean. Ecotoxicol Environ Saf 93:156-162. https://doi.org/10.1016/j.ecoenv.2013.03.034

Kuhl FP, Giardina CR (1982) Elliptic Fourier features of a closed contour. Comput Graph Image Process. https://doi. org/10.1016/0146-664X(82)90034-X

Lestrel PE (1997) Introduction and overview of Fourier descriptors. In: Lestrel PE (ed) Fourier descriptors and their applications in biology. Cambridge University Press, Cambridge, pp 22-43

Libungan LA, Pálsson S (2015) ShapeR: an R package to study otolith shape variation among fish populations. PLoS One 10:e0121102. https://doi.org/10.1371/journal.pone.0121102

Lombarte A, Cruz A (2007) Otolith size trends in marine fish communities from different depth strata. J Fish Biol 71:5376. https://doi.org/10.1111/j.1095-8649.2007.01465.x

Lombarte A, Fortuño JM (1992) Differences in morphological features of the sacculus of the inner ear of two hakes ( Merluccius capensis and M. paradoxus, gadiformes) inhabits from different depth of sea. J Morphol 214:97-107. https://doi.org/10.1002/jmor.1052140107

Lombarte A, Lleonart J (1993) Otolith size changes related with body growth, habitat depth and temperature. Environ Biol Fish 37:297-306. https://doi.org/10.1007/BF00004637

Lombarte A, Tuset V (2015) Morfometria de otólitos. In: Métodos de estudo com otólitos: principios e aplicações. CAFP-BAPIESCI, Buenos Aires, pp 269-302

Losos JB (1990) Ecomorphology, performance capability, and scaling of west Indian Anolis lizards: an evolutionary analysis. Ecol Monogr 60:369-388. https://doi.org/10.2307 $/ 1943062$

Lychakov DV, Redbane YT (1993) Effect of otolith shape on directional sound perception in fish. J Evol Biochem Physiol 28:707-714

Mahe K, Oudard C, Mille T et al (2016) Identifying blue whiting (Micromesistius poutassou) stock structure in the Northeast Atlantic by otolith shape analysis. Can J Fish Aquat Sci. https://doi.org/10.1139/cjfas-2015-0332

Marques JF, Teixeira CM, Pinheiro A et al (2009) A multivariate approach to the feeding ecology of the channel flounder, Syacium micrurum (Pisces, Pleuronectiformes), in Cape Verde, eastern Atlantic. Ciencias Mar 35:15-27

McGill BJ, Enquist BJ, Weiher E, Westoby M (2006) Rebuilding community ecology from functional traits. Trends Ecol Evol 21:178-185. https://doi.org/10.1016/j.tree.2006.02.002

Medeiros PRP, Knoppers BA, Santos-Júnior RC, de Souza WFL (2007) Aporte fluvial e dispersão de matéria particulada em suspensão na zona costeira do rio São Francisco (SE/AL). Geochim Bras 21:212-231

Mendoza-Carranza M, Vieira J (2008) Whitemouth croaker Micropogonias furnieri (Desmarest, 1823) feeding strategies across four southern Brazilian estuaries. Aquat Ecol 42:8393. https://doi.org/10.1007/s10452-007-9084-4

Menezes NA, Figueiredo JL (1980) Manual de Peixes Marinhos do Sudeste do Brasil. IV. Teleostei (3). Museu de Zoologia. Universidade de São Paulo, São Paulo
Menezes NA, Figueiredo JL (1985) Manual de Peixes Marinhos do Sudeste do Brasil. V. Teleostei (4). Museu de Zoologia. Universidade de São Paulo, São Paulo

Micheli F, Halpern BS (2005) Low functional redundancy in coastal marine assemblages. Ecol Lett 8:391-400. https://doi.org/10.1111/j.1461-0248.2005.00731.x

Morales-Nin B (2000) Review of the growth regulation processes of otolith daily increment formation. Fish Res 46:53-67. https://doi.org/10.1016/S0165-7836(00)00133-8

Nonogaki H, Nelson JA, Patterson WP (2007) Dietary histories of herbivorous loricariid catfishes: evidence from $\delta 13 \mathrm{C}$ values of otoliths. Environ Biol Fish 78:13-21. https://doi. org/10.1007/s10641-006-9074-8

Norton SF, Luczkovich JJ, Motta PJ (1995) The role of ecomorphological studies in the comparative biology of fishes. Environ Biol Fish 44:287-304. https://doi.org/10.1007 /BF00005921

O'Toole AC, Murchie KJ, Pullen C et al (2010) Locomotory activity and depth distribution of adult great barracuda (Sphyraena barracuda) in Bahamian coastal habitats determined using acceleration and pressure biotelemetry transmitters. Mar Freshw Res 61:1446-1456. https://doi.org/10.1071 MF10046

Passos CVB, Fabré NN, Malhado ACM, Batista VS, Ladle RJ (2016) Estuarization increases functional diversity of demersal fish assemblages in tropical coastal ecosystems. J Fish Biol 89:847-862. https://doi.org/10.1111/jfb.13029

Paxton JR (2000) Fish otoliths: do sizes correlate with taxonomic group, habitat and/or luminescence? Philos Trans R Soc Biol Sci 355:1299-1303. https://doi.org/10.1098/rstb.2000.0688

Pérez A, Fabré NN (2013) Spatial population structure of the Neotropical tiger catfish Pseudoplatystoma metaense: skull and otolith shape variation. J Fish Biol 82:1453-1468. https://doi.org/10.1111/jfb.12046

Pombo M, Denadai MR, Bessa E, Santos FB, de Faria VH, Turra A (2014) The barred grunt Conodon nobilis (Perciformes: Haemulidae) in shallow areas of a tropical bight: spatial and temporal distribution, body growth and diet. Helgol Mar Res 68:271-279. https://doi.org/10.1007/s10152-014-0387-2

Popper AN, Ramcharitar J, Campana SE (2005) Why otoliths? Insights from inner ear physiology and fisheries biology. Mar Freshw Res 56:497-504. https://doi.org/10.1071/MF04267

Pouilly M, Lino F, Bretenoux JG, Rosales C (2003) Dietarymorphological relationships in a fish assemblage of the Bolivian Amazonian floodplain. J Fish Biol 62:1137-1158. https://doi.org/10.1046/j.1095-8649.2003.00108.x

Quinn TP (2018) The behavior and ecology of Pacific salmon and trout. University of Washington Press

Ramírez-Pérez JS, Quiñónez-Velazquez C, García-Rodríguez FJ et al (2010) Using the shape of sagitta otoliths in the discrimination of phenotypic stocks in Scomberomorus sierra (Jordan and starks, 1895). J Fish Aquat Sci 5:82-93. https://doi.org/10.3923/jfas.2010.82.93

Randall JE (2002) Mullidae: goatfishes. In: Carpenter KE (ed) The living marine resources of the Western Central Atlantic. FAO, Rome, pp 1654-1659

Rasband W (2012) ImageJ. U S Natl Institutes Heal Bethesda, Maryland

Reist JD (1985) An empirical evaluation of several univariate methods that adjust for size variation in morphometric data. Can J Zool 63:1429-1439. https://doi.org/10.1139/z85-213 
Rezzi S, Giani I, Heberger K, Al E (2007) Classification of gilthead sea bream (Sparus aurata) from 1H NMR lipid profiling combined with principal component and linear discriminant analysis. J Agric Food Chem 55:9963-9968. https://doi.org/10.1021/jf070736g

Sabinson LM, Rodrigues-Filho JL, Peret AC, Branco JO, Verani JR (2015) Feeding habits of the congeneric species Stellifer rastrifer and Stellifer brasiliensis (Acanthopterygii: Sciaenidae) co-occurring in the coast of the state of Santa Catarina, Brazil. Braz J Biol 75:423-430. https://doi. org/10.1590/1519-6984.15813

Sadighzadeh Z, Valinassab T, Vosugi G et al (2014) Use of otolith shape for stock identification of John's snapper, Lutjanus johnii (Pisces: Lutjanidae), from the Persian Gulf and the Oman Sea. Fish Res 155:59-63. https://doi.org/10.1016/j. fishres.2014.02.024

Santos MN, Rocha GR, Freire KM (2016) Diet composition for three sciaenids caught off northeastern Brazil. Rev Biol Mar Oceanogr 51:493-504. https://doi.org/10.4067/S071819572016000300002

Schellart NAM, Popper AN (1992) Functional aspects of the evolution of the auditory system of Actinopterygian fish. In: The evolutionary biology of hearing. Springer New York, New York, pp 295-322

Schrandt MN, Powers SP, Mareska JF (2015) Habitat use and fishery dynamics of a heavily exploited coastal migrant, Spanish mackerel. North Am J Fish Manag 35:352-363. https://doi.org/10.1080/02755947.2015.1009659

Schulz-Mirbach T, Ladich F, Plath M, Heß M (2019) Enigmatic ear stones: what we know about the functional role and evolution of fish otoliths. Biol Rev 94:457-482. https://doi. org/10.1111/brv.12463

Schulz-Mirbach T, Ladich F, Riesch R, Plath M (2010) Otolith morphology and hearing abilities in cave- and surfacedwelling ecotypes of the Atlantic molly, Poecilia mexicana (Teleostei: Poeciliidae). Hear Res 267:137-148. https://doi. org/10.1016/j.heares.2010.04.001

Schulz-Mirbach T, Reichenbacher B, Yildirim MZ, Atalay MA (2006) Otolith characteristics of species, subspecies, and populations of Aphanius Nardo, 1827 (Teleostei, Cyprinodontiformes) from Anatolia (Turkey). J Nat Hist 40: 1687-1705. https://doi.org/10.1080/00222930600964498

Secor DH, Dean JM, Laban EH (1992) Otolith removal and preparation for microstructural examination. In: Stevenson DK, Campana SE (eds) Otolith microstructure examination and analysis. Canadian special publication of fisheries and aquatic sciences 117. Departament of Fisheries and Oceans, Ottawa, pp 19-57

Sley A, Jarboui O, Ghorbel M, Bouain A (2009) Food and feeding habits of Caranx crysos from the Gulf of Gabès (Tunisia). J Mar Biol Assoc United Kingdom 89:1375-1380. https://doi. org/10.1017/S0025315409000265

Soares BE, Ruffeil TOB, Montag LF d A (2013) Ecomorphological patterns of the fishes inhabiting the tide pools of the Amazonian coastal zone, Brazil. Neotrop Ichthyol 11:845-858. https://doi.org/10.1590/S167962252013000400013

Souza CD, Batista VS, Fabré NN (2018) What are the main local drivers determining richness and fishery yields in tropical coastal fish assemblages? Zoologia 35:1-12. https://doi. org/10.3897/zoologia.35.e12898
Stransky C, MacLellan SE (2005) Species separation and zoogeography of redfish and rockfish (genus Sebastes) by otolith shape analysis. Can J Fish Aquat Sci 62:2265-2276. https://doi.org/10.1139/f05-143

Tracey SR, Lyle JM, Duhamel G (2006) Application of elliptical Fourier analysis of otolith form as a tool for stock identification. Fish Res 77:138-147. https://doi.org/10.1016/j. fishres.2005.10.013

Tulli MJ, Abdala V, Cruz FB (2011) Relationships among morphology, clinging performance and habitat use in Liolaemini lizards. J Evol Biol 24:843-855. https://doi.org/10.1111 /j.1420-9101.2010.02218.x

Tuset VM, Farré M, Otero-Ferrer JL et al (2016a) Testing otolith morphology for measuring marine fish biodiversity. Mar Freshw Res 67:1037-1048. https://doi.org/10.1071/MF15052

Tuset VM, Imondi R, Aguado G et al (2015) Otolith patterns of rockfishes from the northeastern pacific. J Morphol 276:458469. https://doi.org/10.1002/jmor.20353

Tuset VM, Lozano IJ, Gonzlez JA et al (2003) Shape indices to identify regional differences in otolith morphology of comber, Serranus cabrilla (L., 1758). J Appl Ichthyol 19:88-93. https://doi.org/10.1046/j.1439-0426.2003.00344.x

Tuset VM, Otero-Ferrer JL, Gómez-Zurita J, Venerus LA, Stransky C, Imondi R, Orlov AM, Ye Z, Santschi L, Afanasiev PK, Zhuang L, Farré M, Love MS, Lombarte A (2016b) Otolith shape lends support to the sensory drive hypothesis in rockfishes. J Evol Biol 29:2083-2097. https://doi.org/10.1111/jeb.12932

Vazzoler AEAM (1996) Biologia da reprodução de peixes teleósteos: teoria e prática. EDUEM, Maringá, Maringá

Vega-Cendejas ME, Mexicano-Cíntora G, Arce AM (1997) Biology of the thread herring Opisthonema oglinum (Pisces: Clupeidae) from a beach seine fishery of the Campeche Bank, Mexico. Fish Res 30:117-126. https://doi. org/10.1016/S0165-7836(96)00547-4

Volpedo A, Echeverría DD (2003) Ecomorphological patterns of the sagitta in fish on the continental shelf off argentine. Fish Res 60:551-560. https://doi.org/10.1016/S0165-7836(02)00170-4

Volpedo AV, Tombari AD, Echeverría DD (2008) Ecomorphological patterns of the sagitta of Antarctic fish. Polar Biol 31:635-640. https://doi.org/10.1007/s00300-007-0400-1

Volpedo AV, Cirelli AF (2006) Otolith chemical composition as a useful tool for sciaenid stock discrimination in the SouthWestern Atlantic. Sci Mar 70:325-334. https://doi. org/10.3989/scimar.2006.70n2325

Wainwright PC, Richard BA (1995) Predicting patterns of prey use from morphology of fishes. Environ Biol Fish 44:97133. https://doi.org/10.1007/BF00005909

Watson DJ, Balon EK (1984) Ecomorphological analysis of fish taxocenes in rainforest streams of northern Borneo. J Fish Biol 25:371-384. https://doi.org/10.1111/j.1095-8649.1984. tb04885.x

Williams EE (1972) The origin of faunas. Evolution of lizard congeners in a complex island fauna: a trial analysis. In: Dobzhansky T, Hecht MK, Steere WC (eds) Evolutionary biology. Springer, New York, pp 47-89

Wilson RR (1985) Depth-related changes in sagitta morphology in six Macrourid fishes of the Pacific and Atlantic oceans. Copeia 4:1011-1017. https://doi.org/10.2307/1445256

Winemiller KO (1991) Ecomorphological diversification in lowland freshwater fish assemblages from five biotic regions. 
Ecol Monoghraphs 61:343-365. https://doi.org/10.2307 12937046

Younker JL, Ehrlich R (1977) Fourier biometrics: harmonic amplitudes as multivariate shape descriptors. Syst Biol. https://doi.org/10.1093/sysbio/26.3.336

Zahorcsak P, Silvano RA, Sazima I (2000) Feeding biology of a guild of benthivorous fishes in a sandy shore on south-eastern
Brazilian coast. Rev Bras Biol 60:511-518. https://doi. org/10.1590/S0034-71082000000300016

Publisher's note Springer Nature remains neutral with regard to jurisdictional claims in published maps and institutional affiliations. 